\title{
DETERMINING THE MOST SUITABLE LAYOUT OF SPACE FOR THE LOADING UNITS' HANDLING IN THE MARITIME PORT
}

\author{
Ondrej Stopka, Rudolf Kampf \\ Dept of Transport and Logistics, Institute of Technology and Business in České Budějovice, \\ Czech Republic
}

Submitted 16 October 2014; resubmitted 6 February 2015, 4 July 2015; accepted 8 July 2015;

published online 11 April 2016

\begin{abstract}
The main advantages of maritime transport are (1) lowest costs, (2) large-scale carriage capacity, (3) carriage of different goods over long distances and (4) the most acceptable mode of transport in the context of the environment. This mode of transport is considered more profitable and more cost-effective than all other transport modes. Modern maritime ports have become the essential nodal components of freight transport networks. This paper is focused on determining the most suitable layout of space for the loading units warehousing and handling in the maritime port using the particular method. In the paper, four types of layout and five criteria were taken into account. Layout of warehousing and handling space can affect the entire transport process and can have a great effect on the economics of enterprises.
\end{abstract}

Keywords: maritime port; logistics; loading unit; handling; warehousing; AHP method.

\section{Introduction}

Maritime transport is considered a fundamental part of both global economy and international logistics (Nazari 2005). That is the reason why maritime ports are regarded as meeting points of driving market entities (demand and supply).

Given the significant growth of importance of intermodal transport over recent years and the high utilization of the world's maritime ports, layout of warehousing and handling space in these objects is supposed to be the one of the best way to strengthen their productivity and economics.

It is proved that warehousing and handling space has a direct effect on the loading units stacking (Nazari 2005), reloading and transport operations in maritime ports. Layout of handling space determines the allocation of loading units as well as the transport infrastructure network of the port.

\section{Logistics of Maritime Ports and Transportation Services}

Maritime ports are a key factor of maritime transport system (Seaport Intermodal 2014). Maritime ports have become essential nodal components of freight transport networks. The fundamental concept of maritime ports relates to the specialized zones offering space and common services to the transport operators, logistics providers and shippers.

Maritime ports can generate internal and external effects (Seaport Intermodal 2014). The internal effects refer to advantages for users in sharing the total acquisition and operating costs of common facilities, equipment, and services offered, without heavy and risky investments in building their own. Other benefits stem from increased interaction among users. Freight maritime ports also generate larger-scale or external (network) effects, such as traffic diversion and modal shift, land use reorganization, changes in the local economy and employment, lower energy consumption, and environmental benefits (Drašković 2008; Seaport Intermodal 2014).

Distribution of goods depends on transportation. This is because transportation services in the region rely on transportation network and its development, integration, charges, assortments and quality service. Maritime ports develop various activities related to consolidation; warehousing; storage; handling operations; shipment coordination; services to transport modes, transport units, and human resources; banking; and other cargo administrative services.

They can include many other accompanying activities - packaging (Drašković 2008), coding, marking, 
palletizing, labelling, stowing goods in containers, etc., as well. The core of logistics is creating added - value through fast, efficient, and quality transportation of freight by different means of transport that are on disposal (Tauzović 2001).

\section{Decision-Making Problems}

Selecting the most suitable layout of space for warehousing and handling, the loading units can be viewed as a decision-making problem in which the final decision is influenced by a group of external factors (Edwards 1954).

According to Anderson et al. (2011); Clemen (1997); Dömeová et al. (2006); French $(1986,1989)$ and Keeney, Raiffa (1993), for the purpose of solving the decision-making problems the methods of multi-criteria analysis can be used.

The decision means to choose one option from a list of potentially viable variants against several criteria in a given situation (Belton, Stewart 2002; Brožová et al. 2003). Next to the list of criteria indirectly forming the objective of the decision analysis, it is necessary to have a list of variants from which to choose. Cases where a clearly defined list of potential variants is available are more or less the exception than the rule (DCLG 2009; Zavadskas, Turskis 2011).

The general procedure for the multi-criteria analysis (evaluation of variants) involves six relatively distinct steps (Belton, Stewart 2002; Berger 1985; Fotr et al. 2006; Pearman et al. 1989; Zavadskas, Turskis 2011):

1) identification of variants;

2) establishment of a set of criteria;

3) determination of criteria weightings;

4) determination of criterion examples;

5) partial evaluation of variants;

6) selecting the most suitable variant.
Fiala et al. (1994); Ivaničová and Brezina (1997); Jablonský (2007); Kalčevová (2008); Ramík (1999); Shanteau et al. (1999) and other authors carried-out the analysis of the existing methods used for solving multicriteria analysis issues. Some of them do not take into account the weight of each criterion and therefore are not appropriate for this paper because in the group of criteria, which influence the layout of handling space, significant differences in the importance of criteria exist.

A detailed description of methods of multi-criteria analysis can be found in the following literature as well: Eglese, Hendry (1990); Fotr et al. (2006); Hindls et al. (1997); Stopka et al. (2014a); Zavadskas, Turskis (2011); Zopounidis, Pardalos (2010).

\subsection{Overview of Methods for Determining the Criteria Weightings}

Determining the criteria weightings is closely related to the completeness of a set of criteria reflecting the essential characteristics of the variant. It is usually a crucial step in the analysis of the model of multi-criteria analysis. The information obtained in any way is used to determine the preferential relations between variants depending on the objectives of the entire analysis (Fotr et al. 2006; Triantaphyllou 2000; Saaty et al. 1983).

Methods for determining the weightings (Table 1) can be divided according to the information we have on the preference of criteria (Klicnarová 2010; Mabin, Beattie 2006; Mlynarovič, Hozlár 1993; Saaty et al. 1983; Saaty 1983; Stewart et al. 2013; Zavadskas, Turskis 2011):

- the user has no information;

- methods working with ordinal information;

- methods for determining the weightings of criteria from cardinal information.

No information. The investigators cannot or do not want to decide on the level of preference among the criteria. It is assumed that there is a criteria matrix quantified by cardinal values.

Table 1. Methods for determining the criteria weightings

\begin{tabular}{|c|c|c|}
\hline \multicolumn{3}{|c|}{ Determination of criteria weightings } \\
\hline \multicolumn{3}{|c|}{ Information about preferences among criteria } \\
\hline None & Ordinal & Cardinal \\
\hline Method of equal weights & Method of ranking & Scoring method \\
\hline Entropy method & Method of comparison in Fuller triangle & Saaty's pairwise comparison method \\
\hline \multicolumn{3}{|c|}{ Method of equal weights } \\
\hline \multicolumn{2}{|c|}{$\begin{array}{l}\text { The same weight is assigned to all criteria (Klicnarová 2010; Stopka et al. } \\
\text { 2014a; Zavadskas, Turskis 2011). }\end{array}$} & $\begin{array}{l}\text { Suitability of the method }(\checkmark) \text {. Using the method } \\
\text { for this type of tasks is unsuitable because it does } \\
\text { not allow for the specification of preferences } \\
\text { among criteria. }\end{array}$ \\
\hline \multicolumn{3}{|c|}{ Entropy method } \\
\hline \multicolumn{2}{|c|}{$\begin{array}{l}\text { The method uses the assumption that the criterion is not very important } \\
\text { if the values of all variants in the criteria matrix according to this criterion } \\
\text { are similar; and vice versa, the more the values of individual variants differ, } \\
\text { the more important the criterion is. Therefore, this method can be used to } \\
\text { determine the weightings of the criteria (Jablonský 2007; Kalčevová 2008; } \\
\text { Ríos 1994; Stopka et al. 2014a). }\end{array}$} & $\begin{array}{l}\text { Suitability of the method }(\checkmark) \text {. Using the } \\
\text { method for this type of tasks is unsuitable. To } \\
\text { a certain extent, it allows for the determination } \\
\text { of preference among the criteria; however, this } \\
\text { preference is dependent on the individual values } \\
\text { within the criteria matrix. Moreover, it does not } \\
\text { reflect the true significance of each criterion. }\end{array}$ \\
\hline
\end{tabular}


The method of ranking is primarily used in cases where their importance is evaluated by several experts. Each of the experts arranges the criteria from the most important to the least important. The most important criterion are evaluated by points which correspond to the number of criteria; the second most important criterion will get one point less and so on until the least important criterion only gets 1 point. In case of equal importance of the criteria, these criteria get points according to the average order (Jablonský 2007; Stopka et al. 2014a). According to Goodwin and Wright (2009), Mlynarovič and Hozlár (1993), the weight of each criterion is determined by counting the points given by all experts (for a given criterion); this sum is then divided by the total number of points, which the experts shared between all the criteria. This ensures that the sum of weights of all the criteria is equal to 1.
Suitability of the method $(\checkmark)$. Using the method for this type of tasks is unsuitable. The disadvantage is that the resulting value of the weight is derived from the order and that preference is not given sufficient significance.

\section{Method of comparison in Fuller triangle}

If ordinal information only expresses the relationship between each pair of evaluated criteria, it is possible to use the method of pairwise comparisons. In cases where a user reviews criterion $j$ as being more important than $i$, it also stands that criterion $i$ is considered to be less important than criterion $j$, it is sufficient to perform a number of comparisons ( $n$ is the number of criteria). This comparison is usually done using the so-called Fuller triangle. In each pair of elements, the element, that is considered to be more important, is circled (Belton, Vickers 1993; Kalčevová 2008; Proll et al. 1999).

\section{Scoring method}

The importance of each criterion according to this method is expressed by a certain number of points within the defined scoring scale. Decimal numbers can also be used and more than one criterion may be assigned the same point value. This method is also used for calculating the weights in a similar way to the method of ranking where the criteria are evaluated by several experts. Each expert evaluates each criterion with a certain number of points; the more important the criterion is, the more points it gets (using a scale from 0 to 10 , one criterion may get 0 points from an expert who regards it as insignificant and 10 points from an expert who regards it as absolutely important). The calculation of the weights is done in the same way as in the method of ranking (French 1986, 1989; Mabin, Beattie 2006; Mlynarovič and Hozlár 1993).
Suitability of the method $(\checkmark \checkmark)$. Using the method for this type of tasks is less suitable. The downside, as with the previous method, is the lack of significance given to preference.

\section{Saaty's pairwise comparison method}

This is a method of quantitative pairwise comparison of criteria introduced by Saaty et al. (1983). For the evaluation of paired comparison of criteria, a 9-point scale is used (Zavadskas, Turskis 2011). The researcher compares each pair of criteria and enters the values of preferences of one criterion in relation to another in the Saaty's matrix (Belton, Stewart 2002; Brožová et al. 2003; Ramík 1999; Saaty et al. 1983). The Saaty's method can be used not only to determine the preferences among criteria, but also among variants by analysing the original task, which is overwritten as a hierarchical order (Saaty et al. 1983; Saaty 2008). The detailed description of the Saaty's method is carried-out in the Chapter 3.3.
Suitability of the method $(\checkmark \checkmark)$. Using the method for this type of tasks is less suitable. Scoring the importance of each criterion by a number of experts adds relevance. However, unlike Saaty's method, subjective assessment of the investigators is not eliminated at all.
Ordinal information on the criteria. These methods assume that the investigator is able and willing to express the importance of each criterion by assigning all the criteria their serial numbers or when comparing all pairs of criteria they will decide which criterion from the current pair is more important than the other. In both cases, it is permissible to designate two or more criteria as equal.

Cardinal information about the criteria preferences. These methods assume that the user is able and willing not only to determine the order of importance of the criteria, but the importance of the relationship between all pairs of criteria as well.

\subsection{Overview of Methods for Selecting the Most Suitable Variant}

The aim of this part of the paper is to outline the importance and use of several methods of multi-criteria analysis regarding the selection of the variant and identification of the most suitable one.

Methods for the suitable variant selecting are divided according to what information about the preference among the criteria they require for their work (Brožová et al. 2003; Fotr et al. 2006; Jablonský 2007; Kalčevová 2008; Schum 2013; Stopka et al. 2014a):

- methods not requiring information about preference of criteria; 
- methods requiring aspiration level of criteria;

- methods using ordinal information on the criteria;

- methods requiring cardinal information about the criteria.

Methods that do not require information about the preference between criteria are very simple and in their plain form are rarely used.

For methods that are based on work with aspiration information on preferences between criteria, it is characteristic that they do not try to transform the information of a user into a weight (normalized) vector. Information about the importance of the criteria is expressed as the aspiration level of the criteria. These methods are useful in cases where nominal information is known about the criteria, namely aspiration values of criteria and cardinal evaluation of the variants according to individual criteria.
Methods working with ordinal information about the criteria or variants require a specification of the order of criteria importance and the order of variants according to individual criteria. Some methods are very simple and the results are more or less indicative, others are quite complicated and provide a comprehensive view of the problem.

There are several methods that require cardinal information about the criteria in terms of weights and about the variants in the form of a criteria matrix with cardinal values. In this field, there are three basic approaches to the evaluation of variants. These approaches are divided according to:

- maximization of the benefits;

- maximization of the distance from the ideal variant;

- preferential relationship.

Table 2. Methods for selecting the most suitable variant

\begin{tabular}{|c|c|}
\hline \multicolumn{2}{|l|}{ Simple method of scoring } \\
\hline $\begin{array}{l}\text { This method can be used if the model is specified using only the preference of variants } \\
\text { according to individual criteria and criteria preferences are not known (Fotr et al. } \\
\text { 2006; Jablonsky 2007; Stopka et al. 2014a). }\end{array}$ & $\begin{array}{l}\text { Suitability of the method }(\checkmark) \text {. Using the } \\
\text { method for this type of tasks is unsuitable. } \\
\text { Preferences of the criteria are not known. }\end{array}$ \\
\hline \multicolumn{2}{|c|}{ Simple method of ranking } \\
\hline $\begin{array}{l}\text { The method can be used if the model is specified using only the preference of variants } \\
\text { according to individual criteria and criteria preferences are not known as well (Brožová } \\
\text { et al. 2003; Fotr et al. 2006; Mabin, Beattie 2006). }\end{array}$ & $\begin{array}{l}\text { Suitability of the method }(\checkmark) \text {. Using the } \\
\text { method for this type of tasks is unsuitable. } \\
\text { Preferences of the criteria are not known. }\end{array}$ \\
\hline \multicolumn{2}{|c|}{ Lexicographical method } \\
\hline $\begin{array}{l}\text { The method is based on the principle that the most important criterion has the greatest } \\
\text { influence on the choice of a variant. Only in cases where several variants are rated, } \\
\text { the same is the next most important criterion taken into account. If an alternative } \\
\text { variant is not selected based on this second criterion, the third most important variant } \\
\text { is taken into account, and so on. The algorithm stops at the moment when only one } \\
\text { variant is selected or when all criteria taken into account have been considered. The } \\
\text { alternative variants are then all those that remained equally evaluated after the last } \\
\text { criterion (Brožová et al. 2003; Fotr et al. 2006; Jablonský 2007). }\end{array}$ & $\begin{array}{l}\text { Suitability of the method }(\checkmark) \text {. Using this } \\
\text { method for this type of tasks is unsuitable } \\
\text { because it does not take into account } \\
\text { values obtained by other criteria. }\end{array}$ \\
\hline \multicolumn{2}{|l|}{ Permutation method } \\
\hline $\begin{array}{l}\text { According to DCLG (2009) and Zopounidis, Pardalos (2010), with this method, it } \\
\text { is important to know the order of importance of individual criteria. Further, it is } \\
\text { important to realize that the number of variant permutations } m \text { is } m ! \text {, which is a major } \\
\text { deficiency of this method. For this method, it is necessary to know either the weights } \\
\text { of individual criterion or at least the order of their importance. }\end{array}$ & $\begin{array}{l}\text { Suitability of the method }(\checkmark) \text {. Using } \\
\text { this method for this type of tasks is } \\
\text { unsuitable. It is important to know the } \\
\text { order of importance of individual criteria } \\
\text { and realize that the number of variant } \\
\text { permutations } m \text { is } m \text { ! }\end{array}$ \\
\hline \multicolumn{2}{|l|}{ ORESTE method } \\
\hline $\begin{array}{l}\text { As was stated by Jablonský (2007) and Kalčevová (2008), the method requires as } \\
\text { input only ordinal information on criteria and variants. The investigator is required } \\
\text { to complete quasi-ordering the criteria and to complete quasi-ordering the variants } \\
\text { according to individual criteria i.e. indifference of criteria and variants is permitted. } \\
\text { First, the distance of each variant according to each criterion from the fictional start } \\
\text { is determined (order numbers of the fictional variant and fictional criterion are 0). } \\
\text { Based on this calculated distance, the variants are arranged according to certain rules. }\end{array}$ & $\begin{array}{l}\text { Suitability of the method }(\checkmark) \text {. Using the } \\
\text { method for this type of tasks is unsuitable } \\
\text { because it requires as input only ordinal } \\
\text { information on criteria and variants. }\end{array}$ \\
\hline \multicolumn{2}{|c|}{ Technique for Order of Preference by Similarity to Ideal Solution (TOPSIS) method } \\
\hline $\begin{array}{l}\text { The method is one of the methods where the evaluation of options is performed by } \\
\text { comparison with ideal variants. To express the distance between variants, different } \\
\text { units are used. The TOPSIS method is based on the classical Euclidean metric space } \\
\text { (Fiala et al. 1994; Kalčevová 2008; Stopka et al. 2014a). However, for the calculation of } \\
\text { the final order of variants, it is necessary to know the exact values of individual criteria } \\
\text { assigned to each variant. }\end{array}$ & $\begin{array}{l}\text { Suitability of the method }(\checkmark \checkmark) \text {. Using } \\
\text { this method for this type of tasks is less } \\
\text { suitable. In order to determine the overall } \\
\text { rating for each variant, it is necessary } \\
\text { to know the exact values of the criteria } \\
\text { assigned to individual variants. }\end{array}$ \\
\hline
\end{tabular}


End of Table 2

Weighted Sum Analysis (WSA)

The method requires cardinal information, criteria matrix $Y$ and a vector of criteria weightings $v$. It constructs the overall rating for each variant and so it can be used for finding one of the most suitable variant as well as for arranging variants on a scale from the best to the worst. With this method, we work with the weights of individual criterion, which are either entered or estimated appropriately. Thus, we get the weightings $v=\left(v_{1}, v_{2}, \ldots, v_{k}\right)$ for $k$ of maximization criteria (Ivaničová, Brezina 1997; Jablonský 2007; Stopka et al. 2014a).

The method of weighted sum then maximizes the weighted sum i.e. (Jablonský 2007; Kalčevová 2008):

$$
\sum_{j=1}^{k} v_{j} r_{i j}
$$

Hence, we calculate the value of the weighted sum for each variant and as a compromise variant select the one with the highest weighted sum (Fotr et al. 2006; Jablonský 2007). Similarly to the TOPSIS method, for the calculation of the final order of variants, it is necessary to know the exact values of individual criteria assigned to each variant.

\section{Analytic Hierarchy Process (AHP) method}

This is a method of decomposition of a complex unstructured situation into simpler components, thereby creating a hierarchical system for a problem (Kalčevová 2008; Saaty 1983, 2008). At each level of the hierarchical structure, the Saaty's method of quantitative pairwise comparison is used. Using subjective ratings of pairwise comparison, this method then assigns quantitative characteristics to each component indicating their importance. Synthesis of these evaluations then determines the component with the highest priority, which the investigator focuses on in order to obtain a solution to the decision problem (Saaty 1983, 2008, 2012; Stopka et al. 2014a). This method does not require the exact values of individual criteria assigned to each variant in order to determine the overall order of the variants (Kalčevová 2008; Saaty 1983). The detailed description of the AHP method is carried-out in the Chapter 3.3.
Suitability of the method $(\checkmark \checkmark)$. Using the method for this type of tasks is less suitable. In order to determine the overall rating for each variant, it is necessary to know the exact values of the criteria assigned to individual variants.
Suitability of the method $(\checkmark \checkmark \checkmark)$. Using the method for this type of tasks is suitable. In order to determine the overall order of variants, it is not necessary to know the exact values of the criteria assigned to individual variants.

\section{Data and Methods}

\subsection{Variants Identification}

In stage one, it is necessary to identify a set of variants from which the final solution will be selected. The following different types of handling space layout were identified.

\subsubsection{Handling Space Layout 1: Horizontal Type}

In this variant, the loading units are stacked horizontally, that is parallel to the main railway tracks, reloading tracks and main road infrastructure, as shown in Fig. 1. This type of loading units stacking is used in many maritime ports as a part of modern multimodal logistics centers (Nazari 2005; Seaport Intermodal 2014).

All gantry cranes serve only the loading units stacks cells, possibly even articulated vehicles, not the block trains. Generally, each line of stacks cells is served by one gantry crane or/and by reach-stacker. All block trains and reloading trains are only served by reachstackers. All horizontal roads of this layout are unidirectional. Horizontal roads are used for loading and unloading of articulated vehicles and are suitable for transit routes as well.

All ancillary vertical roads are only used for the transit of articulated vehicles and reach-stackers, not for loading and unloading (Drašković 2008; Nazari 2005; Seaport Intermodal 2014).

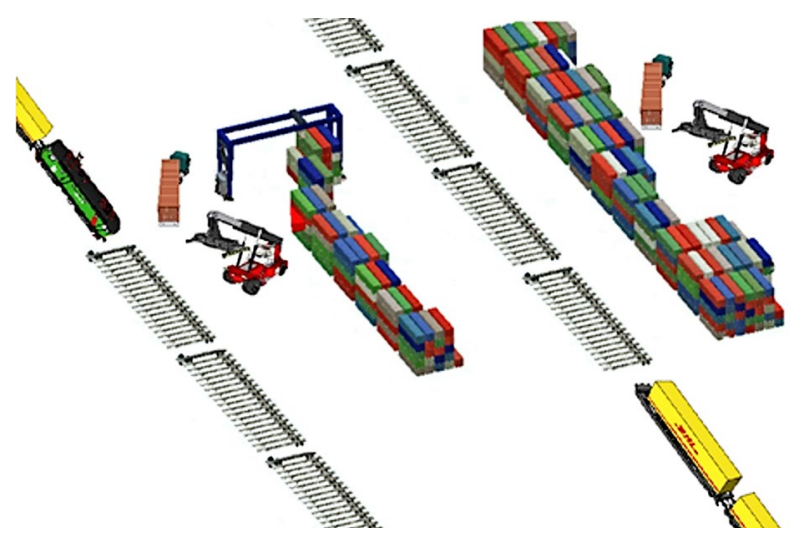

Fig. 1. Horizontal type of handling space layout

\subsubsection{Handling Space Layout 2: Modified Horizontal Type}

In this type of layout, the loading units are stacked in a horizontal position to the main railway tracks, reloading tracks and main road infrastructure as well (Fig. 2) (Drašković 2008; Nazari 2005).

Difference compared with the previous type lies in the fact that all block trains and reloading trains are served by both the gantry cranes and reach-stackers as well. Loading units stacks cells and articulated vehicles are served by one kind of gantry cranes and by reachstackers. Block trains and reloading tracks can be served 


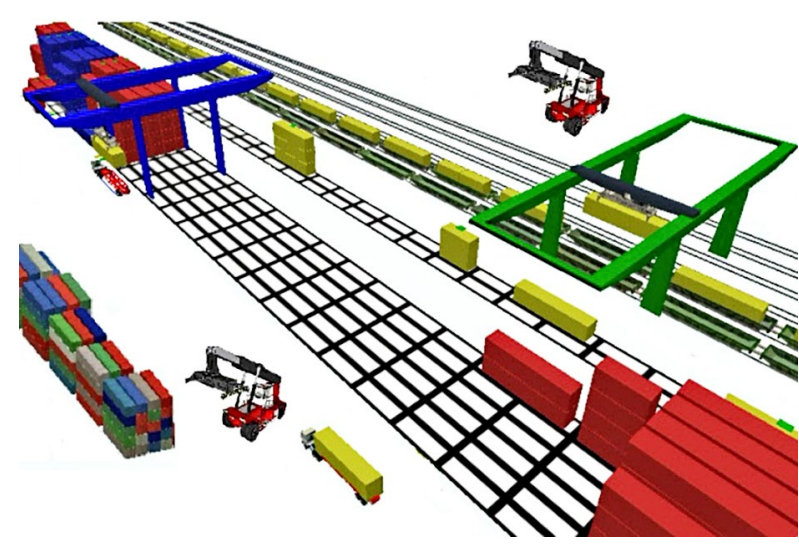

Fig. 2. Modified horizontal type of handling space layout

by reach-stackers and also by another kind of gantry cranes (Nazari 2005; Tauzović 2001).

Given the higher number of cranes compared to the previous variant, the articulated vehicles travel a shorter distance and the traffic is less since a smaller number of vehicles is needed.

Whole road infrastructure is just horizontal type and all roads are unidirectional. Road infrastructure is suitable both for loading and unloading of articulated vehicles by reach-stackers and gantry cranes, and for transit routes. Generally (Tauzović 2001), there are not any vertical roads in the modified horizontal type of layout. Elimination of vertical roads and a smaller number of vehicles cause that the overall handling and warehousing capacity is increased.

\subsubsection{Handling Space Layout 3: Vertical Type}

In this type of layout, loading units are stacked vertically, that is perpendicularly to the main road infrastructure, main railway track and reloading tracks, as shown in Fig. 3 (Drašković 2008; Nazari 2005).

There are ancillary horizontal roads in this layout, which are part of the ring road. These roads are unidirectional and are used both for loading and unloading of vehicles and for the transit. Vertical roads are bidirectional and are used both for loading and unloading of vehicles and for transit routes as well. Roads in this handling space layout provide a faster access to stacks cells.

The cranes serve the vehicles based on first come first served rule. Loading units stacks cells and articulated vehicles are served by gantry cranes and by reachstackers. All block trains and reloading trains can be served only by reach-stackers (Drašković 2008; Nazari 2005; Tauzović 2001).

\subsubsection{Handling Space Layout 4: Combined Type}

Fourth variant presents a combined form of previous layouts (Fig. 4). Loading units are stacked vertically to the main road infrastructure and main railway track and horizontally to the ancillary roads, railway sidings and reloading tracks (Drašković 2008; Nazari 2005; Seaport Intermodal 2014).

In this variant, the articulated vehicles move into the horizontal roads very rarely (in fact, these roads can

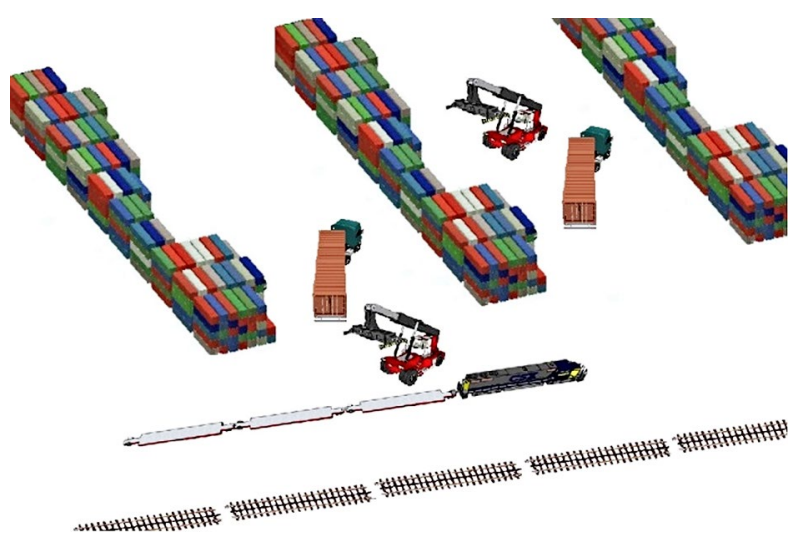

Fig. 3. Vertical type of handling space layout

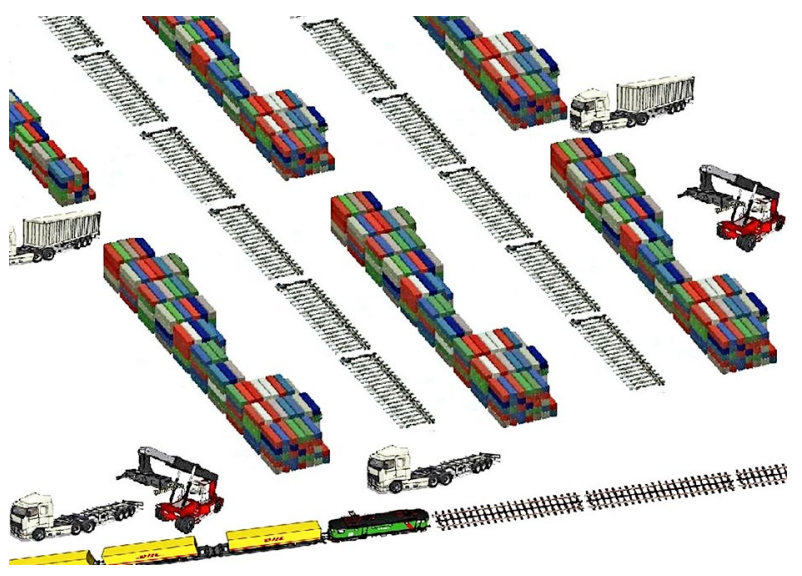

Fig. 4. Combined type of handling space layout

be eliminated in favour of more stacking capacity); instead they are loaded or unloaded at the tail of the line of stacks cells. In most cases, railway sidings and reloading tracks replace the horizontal ancillary roads (Drašković 2008; Tauzović 2001). Gantry cranes have to travel along the stacks cells to load or unload. This means the vehicles travel a shorter distance, gantry cranes and reachstackers are utilized more and the traffic is less since a small number of vehicles is needed.

\subsection{Criteria Identification}

Stage two of the multi-criteria analysis process includes a set of criteria identification, which influences the decision-making process in the context of selecting the suitable variants (Fotr et al. 2006; Kalčevová 2008). Developing a tailor-made system of evaluation criteria is an important step in the whole multi-criteria analysis process, one that can significantly affect the overall outcome of the evaluation (Fotr et al. 2006).

The rational creation of evaluation criteria significantly depends on a thorough knowledge of the object of evaluation and on a systemic understanding of its structure and its functions. The set of criteria must be comprehensive i.e., it must reflect the essential characteristics of the objects (variants). If the latter is not the case, a gross distortion in the results may occur (Fotr et al. 2006; Saaty et al. 1983; Triantaphyllou 2000). 
It is necessary to differentiate the criteria according to the type of preference (Kalčevová 2008): increasing preference (maximization, profit), decreasing preference (minimization, loss) and alternating preference - preference changes when a certain value is achieved.

Decision-making for a typical handling space layout requires considering more than one criterion into account. After determining the objectives of the available knowledge analysis, relevant to this paper, five criteria primarily from transport-economic fields were identified.

While many criteria can be translated into (a) cost, still there are some points that should be looked at in a more qualitative way as we need a design with: (b) minimum loading units' transhipment time, (c) minimization of roads and railway infrastructure to create more warehousing capacity, (d) greater accessibility of handling and handling space for vehicles and trains in switching from import to export area, (e) less traffic as a result of smoother configuration to avoid congestion and less area needed for handling and warehousing space construction.

Actually, this shows the multi-criteria property of decision-making in this regard i.e., we would deem:

- cost (fixed and variable costs);

- loading units' transhipment time (T-time);

- warehousing capacity (W-capacity);

- accessibility and flexibility (A\&F);

- traffic and area (T\&A).

\subsubsection{Cost}

Considering the assumptions in variant 4 , horizontal roads are eliminated i.e., more stacks and there is a need for more gantry cranes, reach-stackers and reloading tracks (Nazari 2005). Apparently, that is the reason why this variant has the highest cost compared to the other ones.

However, this layout needs the least number of articulated vehicles as the distance for vehicles travel is less and more gantry cranes are there to serve. Based on the above-mentioned assumptions, variant 2 is next, then variant 1 and variant 3 is of the least cost (Drašković 2008; Nazari 2005; Seaport Intermodal 2014).

\subsubsection{Loading Units' Transhipment Time (T-time)}

Variant 4 has the minimum T-time with a minimum number of vehicles and less traffic, compared to the other variants. Layout 2 is next, due to a small number of vehicles. Variant 3 is the third in the order and the highest T-time belongs to variant 1 with a same number of vehicles needed. The reason is that dissimilar routings of the variants result in shorter average transhipment time for vehicles in layout 3 compared to those in layout 1 (Drašković 2008; Seaport Intermodal 2014; Tauzović 2001).

\subsubsection{Warehousing Capacity (W-capacity)}

Layout 4 is the most capacious followed by layout 2, 3 and 1 . In layout 4 and 2, one type of roads is eliminated so the warehousing capacity is increased. In addition, the capacity of the variant 2 is higher than variant 3 because of the less road infrastructure used for transhipment of loading units from vehicles (Seaport Intermodal 2014; Tauzović 2001).

\subsubsection{Accessibility and Flexibility (A\&F)}

In terms of using the gantry cranes and reach-stackers in both import and export area and roads as well, layout 3 is the best. Considering the existence of horizontal and vertical roads, layout 1 is suitable in terms of accessibility as well. On the other hand, this layout 1 is not flexible in using gantry cranes. Layout 4 and 2 are flexible in using handling equipment but are not accessible (Nazari 2005; Tauzović 2001).

\subsubsection{Traffic and Area (T\&A)}

As mentioned above, due to small number of articulated vehicles, variant 4 has the least traffic followed by variant 2. Variants 1 and 3 have just as much traffic.

In terms of size of the area needed for handling and warehousing space construction, layout 4 is the best. In this variant, horizontal roads are eliminated and replaced by railway sidings and reloading tracks. In this case, railway infrastructure takes less space so the size of total area can be reduced. A similar case is variant 2 . However, vertical roads eliminated in this layout intended only for transit take less space than eliminated horizontal roads in previous variant. The size of the land for warehousing area of the layout 1 is smaller than layout 3 because of the less road infrastructure used for loading units' transhipment as well (Nazari 2005; Seaport Intermodal 2014; Tauzović 2001).

\subsection{Determining the Key Methods}

Selecting the suitable method depends on the perspective of the investigator interested in the subject. As mentioned above (Chapter 2), there are many different methods of multi-criteria analysis, which can help in selecting the handling space layout. In practice, however, many methods cannot be used because they do not allow for the processing of all the intricacies intended in this issue and the fact that we do not know the details of the customers and users of maritime ports, which we could have analysed (Linkov, Ramadan 2005; Saaty 1983).

On this basis, it was decided to use the AHP method (Saaty 1983, 1986), which appears to be relatively easy to handle and easy to apply to the complex and difficult task of selecting the handling space layout.

In its calculation, the AHP method uses criteria with set weightings. Again, there are several methods to determine the criteria weightings (Chapter 2). For the purposes of this paper, the Saaty's pairwise comparison method (Saaty et al. 1983) was chosen. A number of criteria have lesser or greater effect on the layout selection. It was therefore necessary to choose such a method, which allows human judgment to determine the relationship preference between two criteria being compared. Furthermore, the Saaty's method allows for the detailed division of these preferences (Linkov, Ramadan 2004; Ramík 1999; Saaty et al. 1983). 


\subsubsection{Saaty's Method}

As mentioned above (Chapter 2), this is a method of quantitative pairwise comparison of criteria (Saaty et al. 1983). For the evaluation of paired comparison of criteria, a 9-point scale is used:

- 1 - equal criteria $i$ and $j$;

- 3 - slightly preferred criterion $i$ above $j$;

- 5 - strongly preferred criterion $i$ above $j$;

- 7 - very strongly preferred criterion $i$ above $j$;

- 9 - absolutely preferred criterion $i$ above $j$.

It is possible to use intermediate values $(2,4,6,8)$ as well. Matrix elements $S=\left(s_{i j}\right)$ are interpreted as estimates of the proportion of the weights of the $i$-th and $j$-th criteria (Belton, Stewart 2002; Saaty et al. 1983; Triantaphyllou 2000; Zavadskas, Turskis 2011).

The researcher compares each pair of criteria and enters the values of preferences of $i$-th in relation to the $j$-th criterion in the Saaty's matrix $S=\left(s_{i j}\right)$. In case that $j$-th criterion is preferred above that of the $i$-th criterion, inverse values are entered into the Saaty's matrix $\left(s_{i j}=\right.$ $1 / 3$ for low preference, $s_{i j}=1 / 5$ for strong preference, etc.) (Saaty et al. 1983; Triantaphyllou 2000).

This already indicates the basic characteristics of the Saaty's matrix. Saaty et al. (1983) designed several numerically very simple ways by which the weights can be estimated. Vector of their values are denoted as $v=$ $\left(v_{1}, v_{2}, \ldots, v_{k}\right)$. The most commonly used method of calculating weights is the normalized geometric mean of a row in a Saaty's matrix, the procedure is sometimes called 'logarithmic least squares method' (Saaty et al. 1983; Saaty 1983).

The 'priority vector' i.e., the normalized weight is calculated for each criterion using the geometric mean of each row in the matrix divided by the sum of the geometric means of all the criteria (Kalčevová 2008; Saaty et al. 1983; Saaty 1983).

Calculating the geometric mean of each row of the matrix $S$ :

$$
g_{i}=\sqrt[k]{\prod_{j=1}^{k} s_{i j}}, i, j=1,2, \ldots, k,
$$

where: $g_{i}$ - geometric mean; $s_{i j}$ - elements of Saaty's matrix; $\Pi$ - product of values of Saaty's matrix elements.

Normalization of the geometric mean:

$$
v_{i}=\frac{g_{i}}{\sum_{i=1}^{k} g_{i}}, i, j=1,2, \ldots, k,
$$

where: $v_{i}$ - normalized geometric mean; $g_{i}$ - geometric mean; $\Sigma$ - sum of geometric means' values.

\subsubsection{AHP Method}

The AHP method, first suggested by Saaty (1983) more than three decades ago, is one of the widely used multicriteria decision-making methods. AHP can effectively handle both qualitative and quantitative data to decompose the problem hierarchically where the problem is thoroughly broken down. Concerning the hierarchical level, sub-elements of the problem are listed to the sub-

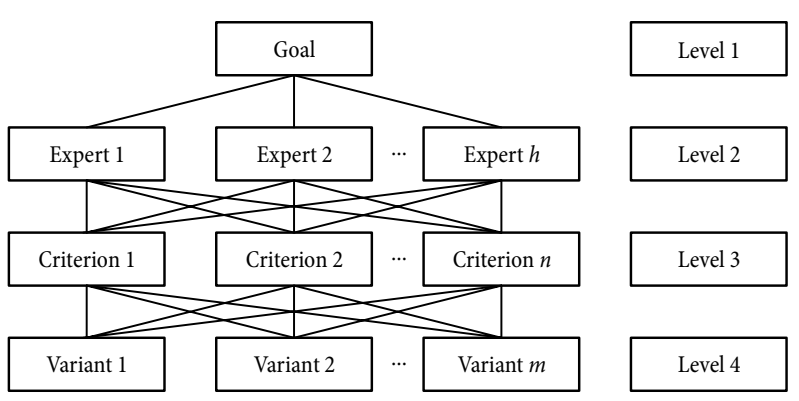

Fig. 5. The AHP method hierarchy structure

objectives in relation with the overall objective (Ramík 2000; Saaty 1986, 2012).

General AHP procedure is composed of four main phases (Fig. 5) (Kalcevova 2008; Saaty 2005, 2008, 2012):

1) hierarchical problem decomposition: identifying the decision problem and overall goal/objective - the problem is decomposed into sub-elements hierarchically (which are structured at different levels in the form of a hierarchy, from the top through the intermediate to the lowerlevel, which usually contains a finite number of decision elements);

2) evaluation phase: the relative importance of each element at a particular level is measured by a procedure of pairwise comparison; decisionmakers provide numerical values for the priority of each element using a rating scale;

3) synthesis of variants (ranking): the priority weights of elements at each level are computed using an eigenvector or least square analysis;

4) result: the above process is repeated for each level of the hierarchy until a decision is finally reached by overall composite weights.

The goal is to select the variant that results in the greatest value of the objective function (Saaty 2012). This is a compensatory optimization approach.

\section{Results and Discussion}

\subsection{Determining the Criteria Weightings}

The first step of the Saaty's method is to determine the relationship between each pair of criteria when the level of significance (preference) is determined in a spot range between 1-9 (Saaty et al. 1983; Saaty 1983). This is determined as follows:

- to ensure the greatest possible objectivity in selecting the suitable warehousing and handling space layout, five experts from the field of intermodal transport, water transport, logistics and freight forwarding were asked to determine preferences between individual criteria; each of the five experts set a level of significance for each pair of criteria;

- for each element of the matrix, a product of the sub-matrices of all experts was established and then the average was calculated.

Subsequently, elements of the Saaty's method were used for further calculations. The individual values obtained from a procedure of the criteria weightings de- 
termining and the values obtained for the individual criterion in the intermediate calculations and the final values of the vector of weights of individual criterion are given in Table 3.

The final product of a consistent pairwise comparison (Saaty's method) is the overall priority vector (normalized geometric mean) of the criteria as illustrated in the last column of Table 3.

Table 3. Values obtained using the Saaty's method

\begin{tabular}{|c|l|c|c|c|c|c|}
\hline \multicolumn{2}{|c|}{ Criterion } & 1 & 2 & 3 & 4 & 5 \\
\hline 1 & Cost & 1 & 3 & 2 & 4 & 5 \\
\hline 2 & T-time & 1.3 & 1 & 1.2 & 2 & 2 \\
\hline 3 & W-capacity & 1.2 & 2 & 1 & 2 & 3 \\
\hline 4 & $A \& F$ & 1.4 & 1.2 & 1.2 & 1 & 1 \\
\hline 5 & $T \& A$ & 1.5 & 1.2 & 1.3 & 1 & 1 \\
\hline Product of values & 120 & 2.3 & 6 & 1.16 & 1.30 \\
\hline Geometric mean & 2.605 & 0.922 & 1.348 & 0.630 & 0.506 \\
\hline $\begin{array}{l}\text { Normalized } \\
\text { geometric mean }\end{array}$ & 0.433 & 0.153 & 0.224 & 0.105 & 0.085 \\
\hline
\end{tabular}

Notes: T-time - loading units' transhipment time; W-capacity warehousing capacity; A\&F - accessibility and flexibility; T\&A - traffic and area.

\subsection{Determining the Most Suitable Variant}

In our case, the AHP method enables to assess the suitability of four determined variants of handling space layout. The order of four handling space layouts based on the overall preferences expressed by the experts' assessment is the outcome of this method.

Assigning the judgment of decision-makers (experts) to each of the criteria was the first step of this method. Subsequently, according to the general AHP procedure, a comparison of individual layouts between them by each determined criterion was performed (Saaty 2008; Stopka et al. 2014a, 2014b).

Again, five experts were asked to determine preferences between individual variants by each criterion. Each of the five experts set a level of significance for each pair of layouts by the corresponding criterion (Kampf et al. 2012). In addition, for each element of the matrixes assessment (Saaty 2012; Stopka et al. 2014b), a product of the sub-matrices of all experts was established and then the average was calculated.

All comparisons of the layouts for each criterion (cost, T-time, W-capacity, A\&F, T\&A) are presented in the following tables (Tables 4-8).

In total, six criteria were determined and for each one its weight was calculated. This weight must be subdivided among the layouts.

Weight of each criterion and also layouts weights according to these criteria were calculated (Tables 3-8).

In order to determine the overall order of layouts, sum of values of each variant by the individual criterion multiplied by the weight of the corresponding criterion was counted.

Subsequently, layouts were placed in descending order whereby the order of variants was identified (Table 9).
Table 4. The comparison matrix of the layouts for cost

\begin{tabular}{|l|c|c|c|c|}
\hline \multicolumn{1}{|c|}{ Cost } & Layout 1 & Layout 2 & Layout 3 & Layout 4 \\
\hline Layout 1 & 1 & 3 & 1.2 & 4 \\
\hline Layout 2 & 1.3 & 1 & 1.5 & 2 \\
\hline Layout 3 & 2 & 5 & 1 & 6 \\
\hline Layout 4 & 1.4 & 1.2 & 1.6 & 1 \\
\hline Geometric mean & 1.565 & 0.604 & 2.783 & 0.381 \\
\hline $\begin{array}{l}\text { Normalized } \\
\text { geometric mean }\end{array}$ & 0.293 & 0.113 & 0.522 & 0.072 \\
\hline
\end{tabular}

Table 5. The comparison matrix of the layouts for loading units' transhipment time (T-time)

\begin{tabular}{|l|c|c|c|c|}
\hline \multicolumn{1}{|c|}{ T-time } & Layout 1 & Layout 2 & Layout 3 & Layout 4 \\
\hline Layout 1 & 1 & $1 / 4$ & $1 / 2$ & $1 / 5$ \\
\hline Layout 2 & 4 & 1 & 3 & $1 / 2$ \\
\hline Layout 3 & 2 & $1 / 3$ & 1 & $1 / 3$ \\
\hline Layout 4 & 5 & 2 & 3 & 1 \\
\hline Geometric mean & 0.398 & 1.565 & 0.686 & 2.340 \\
\hline $\begin{array}{l}\text { Normalized } \\
\text { geometric mean }\end{array}$ & 0.080 & 0.314 & 0.138 & 0.468 \\
\hline
\end{tabular}

Table 6. The comparison matrix of the layouts for warehousing capacity (W-capacity)

\begin{tabular}{|l|c|c|c|c|}
\hline \multicolumn{1}{|c|}{$W$-capacity } & Layout 1 & Layout 2 & Layout 3 & Layout 4 \\
\hline Layout 1 & 1 & $1 / 3$ & $1 / 2$ & $1 / 5$ \\
\hline Layout 2 & 3 & 1 & 2 & $1 / 2$ \\
\hline Layout 3 & 2 & $1 / 2$ & 1 & $1 / 4$ \\
\hline Layout 4 & 5 & 2 & 4 & 1 \\
\hline Geometric mean & 0.426 & 1.316 & 0.707 & 2.515 \\
\hline $\begin{array}{l}\text { Normalized } \\
\text { geometric mean }\end{array}$ & 0.086 & 0.265 & 0.142 & 0.507 \\
\hline
\end{tabular}

Table 7. The comparison matrix of the layouts for accessibility and flexibility (A\&F)

\begin{tabular}{|l|c|c|c|c|}
\hline \multicolumn{1}{|c|}{$A \& F$} & Layout 1 & Layout 2 & Layout 3 & Layout 4 \\
\hline Layout 1 & 1 & 5 & $1 / 3$ & 5 \\
\hline Layout 2 & $1 / 5$ & 1 & $1 / 7$ & 1 \\
\hline Layout 3 & 3 & 7 & 1 & 7 \\
\hline Layout 4 & $1 / 5$ & 1 & $1 / 7$ & 1 \\
\hline Geometric mean & 1.699 & 0.413 & 3.482 & 0.413 \\
\hline $\begin{array}{l}\text { Normalized } \\
\text { geometric mean }\end{array}$ & 0.283 & 0.069 & 0.579 & 0.069 \\
\hline
\end{tabular}

Table 8 . The comparison matrix of the layouts for traffic and area (T\&A)

\begin{tabular}{|l|c|c|c|c|}
\hline \multicolumn{1}{|c|}{$T \& A$} & Layout 1 & Layout 2 & Layout 3 & Layout 4 \\
\hline Layout 1 & 1 & $1 / 4$ & 3 & $1 / 5$ \\
\hline Layout 2 & 4 & 1 & 5 & $1 / 2$ \\
\hline Layout 3 & $1 / 3$ & $1 / 5$ & 1 & $1 / 7$ \\
\hline Layout 4 & 5 & 2 & 7 & 1 \\
\hline Geometric mean & 0.622 & 1.778 & 0.312 & 2.893 \\
\hline $\begin{array}{l}\text { Normalized } \\
\text { geometric mean }\end{array}$ & 0.111 & 0.317 & 0.056 & 0.516 \\
\hline
\end{tabular}


Table 9. Resulting weightings and the order of layouts

\begin{tabular}{|c|c|c|c|c|c|c|c|}
\hline Layout Criterion & 1 & 2 & 3 & 4 & 5 & Sum of values & Order of layouts \\
\hline 1 & 0.293 & 0.080 & 0.086 & 0.283 & 0.111 & 0.197523 & 3 \\
\hline 2 & 0.113 & 0.314 & 0.265 & 0.069 & 0.317 & 0.190521 & 4 \\
\hline 3 & 0.522 & 0.138 & 0.142 & 0.579 & 0.056 & 0.344503 & 1 \\
\hline 4 & 0.072 & 0.468 & 0.507 & 0.069 & 0.516 & 0.267453 & 2 \\
\hline Criteria weightings & 0.433 & 0.153 & 0.224 & 0.105 & 0.085 & - & - \\
\hline
\end{tabular}

\section{Conclusions}

Based on the performed analysis of the existing methods of the multi-criteria analysis (Chapter 2), realized calculations and obtained results (Chapter 4 ), it can be stated that the AHP method can be used as one of the possibilities in the matter of decision-making on the most suitable scenario in handling space layout among four proposed layouts. The horizontal type as the first layout, then the modified form of previous one would be the second layout, the third layout is a vertical type and the fourth layout is a combined form of previous layouts.

In this connection, the following performance criteria have been considered in the decision-making process:

- cost;

- loading units;

- transhipment time;

- warehousing capacity;

- accessibility and flexibility,

- traffic and area.

Ultimately, having considered the above results of the calculations (Table 9) of the overall order of layouts, layout 3 - modified horizontal type appears to be the most suitable handling space layout for the loading units warehousing and handling in the maritime port followed by layout 4, layout 1 and layout 2 .

The AHP method allows for the reduction in the number of criteria that are taken into account in search of solutions (Kalčevová 2008; Ríos 1994).

Preferences differ from one decision-maker (expert) to another; therefore, the outcome depends on who is making the decision and what their goals and preferences are (Goodwin, Wright 2009; Kampf et al. 2012; Mlynarovič, Hozlár 1993).

Furthermore (Stopka et al. 2014b; Tauzović 2001), in future the managers and operators of maritime ports should be more involved with non-monitory issues and decision criteria, such as environmental issues like air and noise pollution etc.

\section{References}

Anderson, D. R.; Sweeney, D. J.; Williams, T. A.; Camm, J. D.; Martin, R. K. 2011. An Introduction to Management Science: Quantitative Approaches to Decision Making. SouthWestern College Pub. 896 p.

Belton, V.; Stewart, T. 2002. Multiple Criteria Decision Analysis: an Integrated Approach. Springer. $372 \mathrm{p}$.

http://doi.org/10.1007/978-1-4615-1495-4
Belton, V.; Vickers, S. P. 1993. Demystifying DEA - a visual interactive approach based on multiple criteria analysis, The Journal of the Operational Research Society 44(9): 883-896. http://doi.org/10.2307/2584181

Berger, J. O. 1985. Statistical Decision Theory and Bayesian Analysis. Springer. 618 p.

http://doi.org/10.1007/978-1-4757-4286-2

Brožová, H.; Houška, M.; Šubrt, T. 2003. Modely pro vícekriteriální rozhodování. Praha: Česká zemědělská univerzita v Praze. 172 s. (in Czech).

Clemen, R. T. 1997. Making Hard Decisions: An Introduction to Decision Analysis. 2nd edition. Duxbury. 664 p.

DCLG. 2009. Multi-Criteria Analysis: a Manual. Department for Communities and Local Government (DCLG), London, 168 p. Available from Internet: https://www.gov.uk/ government/uploads/system/uploads/attachment_data/ file/7612/1132618.pdf

Dömeová, L.; Houška, M.; Beránková, M. 2006. Multiple-criteria approach for strategy adaptation in SME's, Agricultural Economics 52(4): 155-159.

Drašković, M. 2008. Integrisana marketing logistika u sistemu menadžmenta Luke Bar: menadžment u pomorstvu. Kotor: Fakultet za pomorstvo. 206 p. (in Serbian).

Edwards, W. 1954. The theory of decision making, Psychological Bulletin 51(4): 380-417. http://doi.org/10.1037/h0053870

Eglese, R. W.; Hendry, L. 1990. Operational Research Tutorial Papers. Birmingham: Operational Research Society. 170 p.

Fiala, P.; Jablonský, J.; Maňas, M. 1994. Vícekriteriální rozhodování. Praha: Vysoká škola ekonomická v Praze. 316 s. (in Czech).

French, S. 1989. Readings in Decision Analysis. Chapman and Hall/CRC. 224 p.

French, S. 1986. Decision Theory: an Introduction to the Mathematics of Rationality. Ellis Horwood, Ltd. 448 p.

Fotr, J.; Švecová, L.; Dědina, J.; Hrůzová, H.; Richter, J. 2006. Manažerské rozhodování: postupy, metody a nástroje. Praha: Ekopress. 410 s. (in Czech).

Goodwin, P.; Wright, G. 2009. Decision Analysis for Management Judgment. 4th edition. Wiley. 468 p.

Hindls, R.; Kaňoková, J.; Novák, I. 1997. Metody statistické analýzy pro ekonomy. Praha: Management Press. 250 s. (in Czech).

Ivaničová, Z.; Brezina, I. 1997. Kvantitatívne metódy pre manažérov. Bratislava: IURA Edition. 250 s. (in Slovak).

Jablonský, J. 2007. Operační výzkum: kvantitativní modely pro ekonomické rozhodování. Praha: Professional Publishing. 323 s. (in Czech).

Kalčevová, J. 2008. Kriteriální matice a hodnocení variant. 8 p. Available from Internet: http://jana.kalcev.cz/vyuka/kestazeni/EKO422-KriterialniMatice.pdf (in Czech). 
Kampf, R.; Lizbetin, J.; Lizbetinova, L. 2012. Requirements of a transport system user, Communications (4): 106-108.

Keeney, R. L.; Raiffa, H. 1993. Decisions with Multiple Objectives: Preferences and Value Tradeoffs. Cambridge University Press. 592 p.

Klicnarová, J. 2010. Vícekriteriální hodnocení variant. $21 \mathrm{~s}$. Available from Internet: http://home.ef.jcu.cz/ janaklic/ oa_zsf/VHV_I.pdf (in Czech).

Linkov, I.; Ramadan, A. B. 2005. Comparative Risk Assessment and Environmental Decision Making. Springer Netherlands. 322 p. http://doi.org/10.1007/1-4020-2243-3

Mabin, V.; Beattie, M. 2006. A Practical Guide to Multi-Criteria Decision Analysis: A Workbook Companion to VISA. 5th edition. Victoria University of Wellington. 109 p. Available from Internet: http://www.victoria.ac.nz/som/researchprojects/publications/Mulit-Criteria_Decision_Analysis.pdf

Mlynarovič, V.; Hozlár, E. 1993. Viackriteriálne rozhodovanie. Bratislava: Ekonomická univerzita. 206 s. (in Slovak).

Nazari, D. 2005. Evaluating Container Yard Layout: a Simulation Approach: MSc Thesis. Erasmus University Rotterdam, Netherlands.

Pearman, A. D.; Mackie, P. J.; May, A. D.; Simon, D. 1989. The use of multicriteria techniques to rank highway investment proposals, in A. G. Lockett, G. Islei (Eds.). Improving Decision Making in Organisations: Proceedings of the Eighth International Conference on Multiple Criteria Decision Making Held at Manchester Business School, 21-26 August 1988, University of Manchester, UK, 157-165. http://doi.org/10.1007/978-3-642-49298-3_15

Proll, L. G.; Salhi, A.; Rios Insua, D. 1999. Improving an Optimization-Based Framework for Sensitivity Analysis in Multi-Criteria Decision Making. Report 1999.14. University of Leeds, UK. 14 p.

Ramík, J. 2000. Analytický hierarchický proces (AHP) a jeho využití v malém a středním podnikání. Karviná: Slezská univerzita v Opavě. 221 s. (in Czech).

Ramík, J. 1999. Vícekriteriální rozhodování - analytický hierarchický proces $(A H P)$. Karviná: Slezská univerzita v Opavě. 211 s. (in Czech).

Ríos, S. 1994. Decision Theory and Decision Analysis: Trends and Challenges. Springer Netherlands. 294 p. http://doi.org/10.1007/978-94-011-1372-4

Saaty, T. L.; Vargas, L. G.; Wendell, R. E. 1983. Assessing attribute weights by ratio, Omega: the International Journal of Management Science 11(1): 9-13. http://doi.org/10.1016/0305-0483(83)90078-6

Saaty, T. L. 1983. Priority setting in complex problems, IEEE Transactions on Engineering Management EM-30(3): 140155. http://doi.org/10.1109/TEM.1983.6448606

Saaty, T. L. 1986. Axiomatic foundation of the analytic hierarchy process, Management Science 32(7): 841-847. http://doi.org/10.1287/mnsc.32.7.841

Saaty, T. L. 2012. Decision Making for Leaders: the Analytic Hierarchy Process for Decisions in a Complex World. 3rd revised edition. RWS Publications. 323 p.

Saaty, T. L. 2005. Theory and Applications of the Analytic Network Process: Decision Making with Benefits, Opportunities, Costs, and Risks. 3rd edition. RWS Publications. 352 p.

Saaty, T. L. 2008. Decision making with the analytic hierarchy process, International Journal of Services Sciences 1(1): 83-98. http://doi.org/10.1504/IJSSCI.2008.017590

Shanteau, J.; Mellers, B. A.; Schum, D. 1999. Decision Science and Technology: Reflections on the Contributions of Ward Edwards. Springer. 434 p.
Schum, D. A. 2013. Decision analysis, in S. I. Gass, M. C. Fu (Eds.). Encyclopedia of Operations Research and Management Science, 367-372. http://doi.org/10.1007/9781-4419-1153-7_215

Seaport Intermodal. 2014. Official website of the company. Available from Internet: http://seaportint.com

Stewart, T. J.; French, S.; Rios, J. 2013. Integrating multicriteria decision analysis and scenario planning: review and extension, Omega: the International Journal of Management Science 41(4): 679-688. http://doi.org/10.1016/j.omega.2012.09.003

Stopka, O.; Kampf, R.; Koláŕ, J.; Kubasáková, I. 2014a. Identification of appropriate methods for allocation tasks of logistics objects in a certain area, Naše more 61(1-2): 1-6.

Stopka, O.; Kampf, R.; Kolář, J.; Kubasáková, I.; Savage, C. 2014b. Draft guidelines for the allocation of public logistics centres of international importance, Communications (2): 14-19.

Tauzović, J. T. 2001. Sistemska teorija upravljanja: drugi dio: primjena u morskom brodarstvu i lukama. Podgorica: Univerzitet Crne Gore. 817 p. (in Serbian).

Triantaphyllou, E. 2000. Multi-Criteria Decision Making Methods: a Comparative Study. Springer. 290 p.

Zavadskas, E. K.; Turskis, Z. 2011. Multiple criteria decision making (MCDM) methods in economics: an overview, Technological and Economic Development of Economy 17(2): 397-427. http://doi.org/10.3846/20294913.2011.593291

Zopounidis, C.; Pardalos, P. M. 2010. Handbook of Multicriteria Analysis. Springer Berlin Heidelberg. 455 p. http://doi.org/10.1007/978-3-540-92828-7 